PURBAWIDYA: Jurnal Penelitian dan Pengembangan Arkeologi p-ISSN: 2252-3758, e-ISSN: 2528-3618 Terakreditasi Kementerian Ristekdikti No. 21E/KPT/2018 Vol. 8 (2), November 2019, pp 79 - 96 DOI: https://doi.org/10.24164/pw.v8i2.306

\title{
EKSPLOITASI SUIDAE PADA KALA HOLOSEN DI LIANG PANNININGE, MAROS, SULAWESI SELATAN
}

\section{Exploitation of Suidae During the Holocene Period at Liang Panningnge, Maros, South Sulawesi}

\author{
Muh. Saiful' ${ }^{1)}$, Anggraeni') \\ ${ }^{1)}$ Balai Arkeologi Sulawesi Selatan \\ Jl. Pajjaiyang No 13, Sudiang Raya, Makassar \\ E-mail: ifulk_fullah@yahoo.co.id \\ 2) Departemen Arkeologi Fakultas Ilmu Budaya Universitas Gadjah Mada \\ Jl. Sosio Humaniora, Bulaksumur, Caturtunggal, Sleman, Yogyakarta \\ E-mail: anggra_eni@ugm.ac.id
}

Naskah diterima:15 Juli 2019 - Revisi terakhir: 21 November 2019

Disetujui terbit: 28 November 2019 - Tersedia secara online: 30 November 2019

\begin{abstract}
Liang Panningnge, one of cave sites in Maros Region, South Sulawesi, provides information about the exploitation of animals especially pig (Suidae) by the cave inhabitants. The aim of this research to know more about the behavior and subsistence strategy related to the existence of Suidae. The methods of analyses includes tafonomy analysis, species and elements identification, Number of Identified Specimen (NISP), Minimum Number of Individuals (MNI), Minimum Number of Elements (MNE), age of death, and Linear Enamel Hypoplasia (LEH) analyses. The results showed that there were two species of Suidae that were consumed along the four occupation phases at Liang Panningnge, i.e. Sus celebensis and Babyrousa celebensis. The existence of Toalean tools, especially Maros point and other stones points throughout the habitation period showed that both species of Suidae were hunted. Incomplete elements of each species showed that the preys were possibly butchered inside and outside the site, and specific elements were shared among the group members. There was an indication of management or even domestication of Suidae as shown by the high index of LEH in the third phase. This notion is also supported by significant increase of juvenile and immature Suidae.
\end{abstract}

Keywords: Suidae, Liang Panningnge, Toalean, subsistence strategy

\begin{abstract}
Abstrak
Liang Panningnge, salah satu situs gua di Kabupaten Maros, Sulawesi Selatan, telah memberikan informasi tentang eksploitasi hewan, khususnya babi (suidae) oleh penghuni gua tersebut. Tujuan penelitian ini adalah mengetahui lebih lanjut mengenai tingkah laku dan strategi subsistensi terkait dengan keberadaan suidae. Metode analisis yang digunakan meliputi analisis tafonomi, identifikasi spesies dan elemen, analisis Number of Identified Pecimen (NISP), Minimum Number of Individu (MNI), Minimum Number of Element (MNE), usia kematian, dan Linear Enamel Hypoplasia (LEH). Hasil penelitan
\end{abstract}


menunjukkan bahwa terdapat dua spesies suidae yang dikonsumsi pada keempat fase penghunian Liang Panningnge, yaitu Sus celebensis dan Babyrousacelebensis. Keberadaan alat-alat Toalean, khususnya lancipan Maros dan lancipan batu lainnya sepanjang masa penghunian situs, menunjukkan bahwa kedua spesies tersebut didapatkan dengan cara berburu. Studi terhadap elemen suidae menunjukkan bahwa penjagalan hasil buruan telah dilakukan di dalam dan di luar lingkungan situs, kemudian dipilih dan dibagikan kepada anggota kelompok. Pada fase ke-3 penghunian gua terdapat indikasi pemeliharaan suidae, yang ditunjukkan dengan Indeks LEH yang tinggi serta didukung oleh peningkatan persentase suidae yang usia muda.

Kata kunci: suidae, Liang Panningnge, Toalean, strategi subsistensi

\section{LATAR BELAKANG}

Babi (famili suidae) merupakan hewan yang memiliki peranan penting dalam kehidupan manusia pada berbagai kelompok budaya dari kala akhir plistosen atas (Aubert, M. et al., 2014) hingga saat ini. Kelompok budaya tersebut membangun hubungan dengan membawa suidae masuk dalam lingkungan hidupnya melalui perburuan dan pemeliharaan. Kegiatan pemeliharaan berperan dalam menjamin pemenuhan kebutuhan protein dan aktivitas upacara mereka (Suroto, 2014; Imanuella, 2017).

Hubungan antara suidae dengan manusia pada masa lalu, khususnya pada kala holosen di kawasan karst Maros, Sulawesi Selatan diketahui berdasarkan temuan hasil ekskavasi di situs-situs gua. Ekskavasi yang telah dilakukan di situs-situs tersebut berhasil menemukan artefak-artefak yang dikenal sebagai budaya Toalean, seperti Maros Point, bilah berpunggung, mikrolit, serta artefak tulang dengan tipe bipoint (Heekeren, 1972; Mulvaney \& Soejono, 1970; Olsen \& Glover, 2004). Spesimen suidae yang mayoritas ditemukan bersama dengan artefak-artefak Toalean mengindikasikan bahwa pendukung budaya Toalean telah menjadikan suidae sebagai salah satu hewan yang berperan penting dalam pemenuhan kebutuhan protein mereka. Peranan tersebut ditunjukkan dengan jumlah spesimen suidae yang lebih banyak jika dibandingkan dengan hewan lainnya, misalnya di kawasan karst Maros, yaitu di Ulu Leang (Simons \& Bulbeck, 2004), di kawasan karst Bontocani, Kabupaten Bone, yaitu di Situs Liang Balang Metti dan Situs Liang Cappa Lombo (Fakhri, 2018).

Spesimen suidae yang ditemukan di situs-situs gua di Sulawesi Selatan bersama peralatan batu, seperti lancipan atau mata panah, merupakan bukti cara perolehan suidae dengan berburu (Glover, 1975; Tim Penelitian Kerja Sama Universitas Hasanuddin, Universitas Sains Malaysia, 2016; Hasanuddin, 2017; Fakhri, 2018). Dua spesies suidae yang merupakan hewan endemik Sulawesi, yaitu Sus celebensis dan Babyrousa celebensis (Meijaard, Haile, Gongora, \& Larson, 2015) hadir dalam konteks budaya Toalean dalam rentang waktu 8000 BP sampai dengan 2820 BP (Mulvaney \& Soejono, 1970; Glover, 1975). Posisi suidae pada kurun waktu tersebut tampaknya bukan sekadar sebagai hewan buruan, mengingat terdapat indikasi bahwa Sus celebensis telah mengalami translokasi (Groves, 2006), yaitu ke Pulau Flores pada masa 7000 tahun yang lalu (Berg, 2009), ke Pulau Timor 
(Groves, 2006), dan ke Pulau Halmahera (Albarella, Dobney, \& Rowley-Konwy, 2006). Translokasi tersebut merupakan petunjuk adanya campur tangan manusia terhadap persebaran populasi Sus celebensis di masa lalu.

Selain di situs-situs gua, Sus celebensis dan Babyrousa celebensis juga ditemukan di dua situs terbuka dengan konteks budaya neolitik di lembah Sungai Karama, wilayah Kecamatan Kalumpang, Sulawesi Barat, yaitu Situs Kamassi dan Minanga Sipakko. Selain kedua spesies suidae tersebut, dapat diidentifikasi pula keberadaan Sus scrofa di kedua situs neolitik tersebut melalui gigi molar 3 yang berukuran jauh di atas rata-rata (Anggraeni, 2012; Anggraeni, Simanjuntak, Bellwood, \& Piper, 2014). Kehadiran Sus scrofa yang bukan merupakan hewan endemik Sulawesi menjadi bukti adanya translokasi suidae yang telah dipelihara atau didomestikasi. Spesimen yang ditemukan di kedua situs menunjukkan indikasi dua cara perolehan suidae, yaitu berburu dan memelihara. Indikasi pemeliharaan suidae sebelum 1000 BC ditunjukkan pula dengan keberadaan babi usia muda dalam konteks permukiman neolitik tersebut (Anggraeni, 2012; Anggraeni et al., 2014). Aktivitas pemeliharaan tersebut tampaknya juga diberlakukan terhadap spesies suidae selain Sus scrofa.

Suidae juga ditemukan di Situs Buttu Batu yang terletak di Kabupaten Enrekang. Suidae di situs tersebut ditemukan bersama dengan artefak yang berciri neolitik (Tim Penelitian Balar Sul-Sel, 2016; Hasanuddin, 2018). Akan tetapi, belum diketahui apakah suidae di situs ini hanya merupakan hewan buruan ataukah juga ada indikasi pemeliharaan.
Bukti pemeliharaan suidae telah dijumpai pada beberapa situs neolitik di Asia Tenggara, yaitu di Situs An Son, Vietnam pada masa 2100 BC (P. J. Piper et al., 2014), di Situs Nagsabaran, Luzon, Filipina pada masa 4000 BP (Philip J. Piper, Campos, \& Hung, 2009; P. J. Piper, Hung, Campos, Belwood, \& Santiago, 2009), di Situs Loc Gian, Vietnam pada masa 1900 BC (P. J. Piper et al., 2017), serta di Situs Rach Nui, Vietnam pada masa 1500-1300 BC (P. J. Piper et al., 2017). Bukti dari situs-situs tersebut menjelaskan bahwa pemeliharaan suidae di Asia Tenggara pada dasarnya telah berlangsung pada masa neolitik. Pada masa itu perburuan bukan lagi satu-satunya cara manusia untuk mendapatkan protein hewani, melainkan manusia juga sudah mengenal domestikasi hewan, termasuk suidae (Larson \& Fuller, 2014; Vigne, Carrere, Briois, \& Guilaine, 2011).

Hasil penelitian tahun 2016 dan 2017 di Liang Panningnge yang terletak di Kecamatan Mallawa, Kabupaten Maros, Sulawesi Selatan menunjukkan bahwa bahwa jenis makanan penghuni gua terdiri atas hewan Muridae, Ailorups ursinus, Babyrousa sp., Sus celebensis, Anoa sp., dan Ciropthera (Hasanuddin, 2017; Tim Penelitian Kerja Sama Universitas Hasanuddin, Universitas Sains Malaysia, 2016). Jumlah individu terbanyak di antara hewan-hewan tersebut adalah suidae. Suidae tidak hanya ditemukan bersama dengan artefak Toalean pada keempat fase penghunian gua, tetapi juga satu konteks dengan temuan artefak yang berciri budaya neolitik pada penghunian fase ke-3 di Situs Liang Panningnge (Saiful, 2019). Ditemukannya aktivitas pemeliharaan suidae pada beberapa situs neolitik di Asia Tenggara menjadi dasar untuk menelusuri 
latar belakang keberadaan suidae di Situs Liang Panningnge. Berdasarkan alasan tersebut, rumusan masalah dalam penelitian ini adalah sebagai berikut.

1. Bagaimanakah bentuk eksploitasi suidae yang dilakukan oleh penghuni Liang Panningnge?

2. Apakah pemeliharaan ataudomestikasi spesies suidae sudah dilakukan oleh penghuni Liang Panningnge?

Pertanyaan tersebut ditujukan untuk memberikan gambaran mengenai tingkah laku manusia dalam kaitannya dengan keberadaan suidae dan menjelaskan strategi subsistensi pendukung budaya Toalean di Liang Panningnge pada kala holosen (Gambar 1).

Temuan arkeologis yang menjadi fokus penelitian ini adalah sisa tulang dan gigi suidae serta asosiasinya dengan artefak yang berasal dari dua kotak ekskavasi Liang Panningnge tahun 2015 (S8T5 dan
S16T6; Gambar 2). Jumlah keseluruhan spesimen suidae yang ditemukan di kedua kotak tersebut adalah 2505, berasal dari semua layer hunian di Liang Panningnge, yaitu Layer 1 yang merupakan layer paling atas hingga Layer 4 yang paling bawah (Lihat lampiran Tabel 1).

Analisis yang dilakukan terhadap spesimen suidae dalam penelitian ini meliputi analisis tafonomi, identifikasi spesies dan elemen, analisis Number of Identified Specimen (NISP), Minimal Number of Individu (MNI), Minimal Number of Element (MNE), usia kematian, dan Linear Enamel Hypolasia (LEH). Informasi yang berkaitan dengan aktivitas perburuan dikumpulkan melalui wawancara terhadap responden yang pernah terlibat dalam aktivitas perburuan pada masa sekarang di Sulawesi Selatan. Informasi yang dikumpulkan berupa cara berburu suidae, waktu berburu, serta cara mereka memperlakukan hasil buruannya.

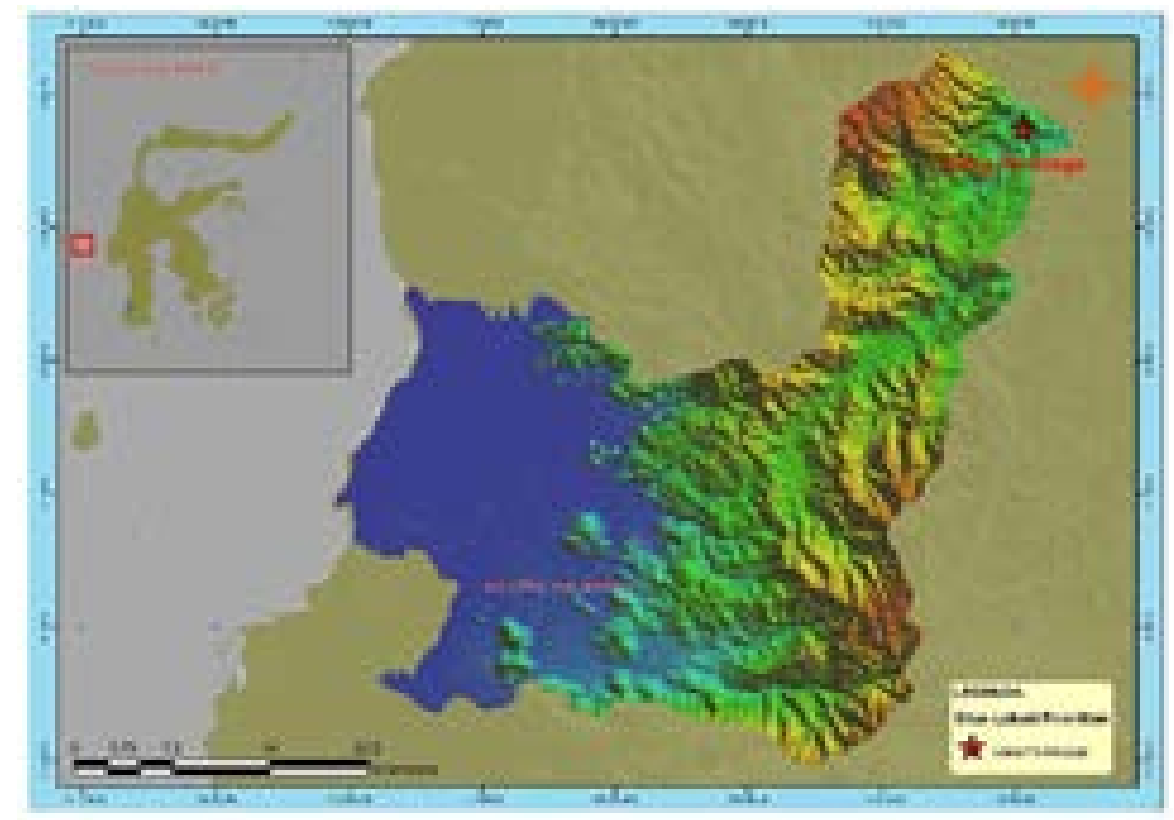

Gambar 1. Letak Situs Liang Panningnge di Kabupaten Maros (Gambar oleh Fardi Ali Syahdar, 2019) 


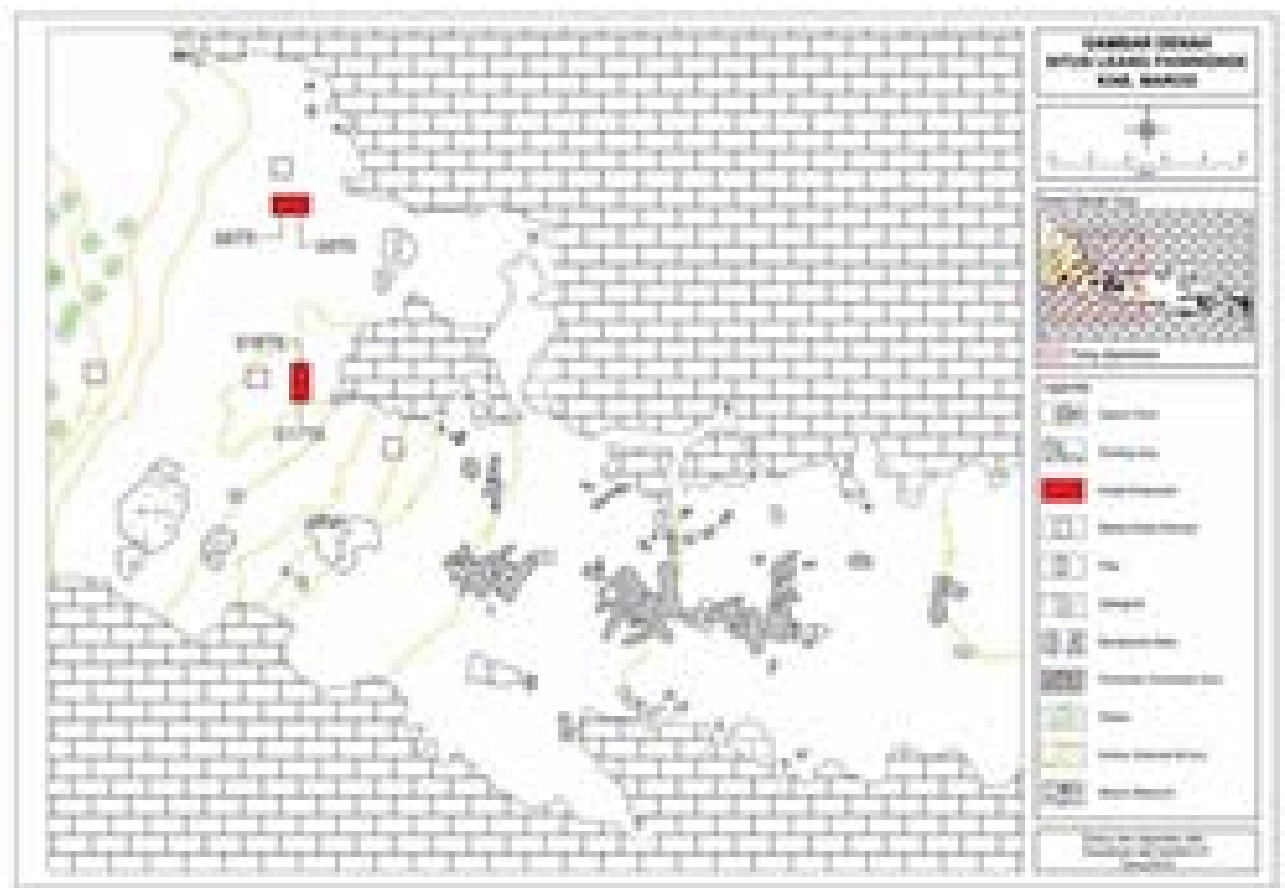

Gambar 2. Denah Situs Liang Panningnge dan letak kotak ekskavasi

(Sumber: Dokumen Tim penelitian kerja sama, 2016; gambar oleh Suryatman dan Asten, 2016)

Tujuan analisis tafonomi adalah untuk memastikan apakah kerusakan spesimen suidae terjadi secara alami, akibat aktivitas hewan atau aktivitas manusia. Jejak aktivitas manusia, seperti penjagalan, dapat diketahui dari adanya jejak cutmark, chop mark, dan punc mark (O'Connor, 2000; Reitz \& Wing, 2008; Fernandes \& Andrews, 2016). Cut mark dicirikan dengan jejak berupa striasi yang paralel berbentuk $V$, panjang ataupun pendek, tipis, lurus, yang dihasilkan akibat proses melepas kulit hewan dan memotog-motong daging menjadi unit yang lebih kecil. Chop mark dicirikan dengan jejak yang lebih dalam berbentuk $V$ yang tidak simetris, akibat tekanan yang lebih kuat dengan menggunakan artefak yang berukuran besar, seperti kapak. Punch mark atau percussion mark adalah kerusakan tulang yang menghasilkan bentuk conchoidal yang diakibatkan oleh pukulan dengan menggunakan batu atau benda keras lainnya.

Penentuan spesies suidae yang terdapat di Liang Panningnge dilakukan dengan melakukan analisis bentuk gigi seri (incisor), taring (canine), premolar, dan molar, serta melakukan pengukuran (biometrik) terhadap gigi molar 3 . Identifikasi setiap elemen dilakukan dengan mengacu referensi, foto anatomi, ataupun koleksi spesimen suidae.

Hasil identifikasi spesimen kemudian dianalisis dengan metode NISP (Number of identified Specimen), MNI (Minimum Number of Individu), dan MNE (Minimum Number of Element). NISP adalah penghitungan jumlah spesimen yang elemen dan taksonnya dapat diidentifikasi (Lyman, 2008). MNI adalah metode penghitungan jumlah individu atau spesies dengan cara menentukan elemen sebelah kiri atau kanan (body side) (Sutton 
\& Arkuhs, 1996). MNE digunakan untuk menghitung jumlah elemen yang ditemukan berdasarkan unit terkecil elemen (part of element) (Lyman, 2008).

Identifikasi usia kematian didasarkan pada tingkat penggunaan gigi (tooth wear stage) yang diperkenalkan oleh Elizabeth Wright dkk. (Wright, Viner-Daniels, Pearson, \& Albarella, 2014) (Lihat lampiran Tabel2). Identifikasi ini bertujuan untuk mengetahui kecenderungan usia kematian suidae yang terdapat di Liang Panningnge.
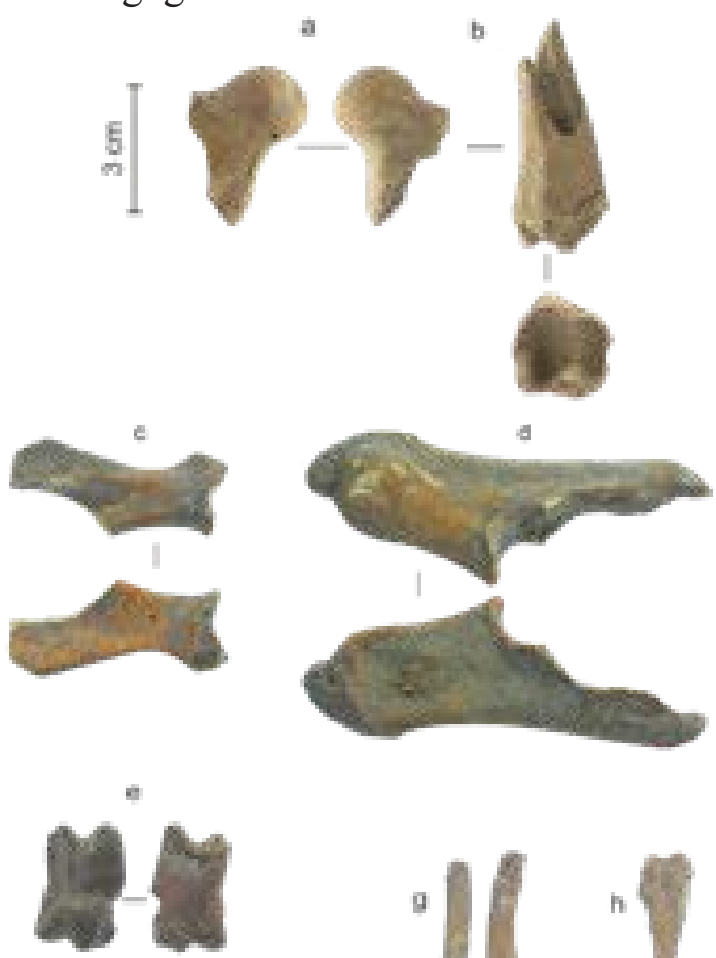

प

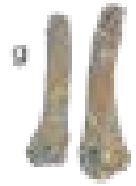

h
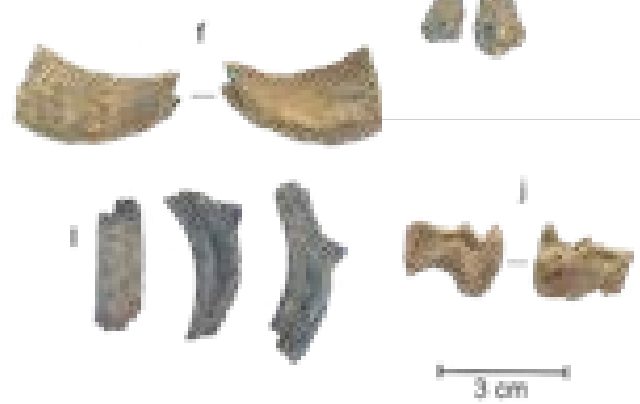

Gambar 3. Spesimen Tulang Suidae yang ditemukan di Liang Panningnge (Sumber: Dokumen Saiful, 2019)
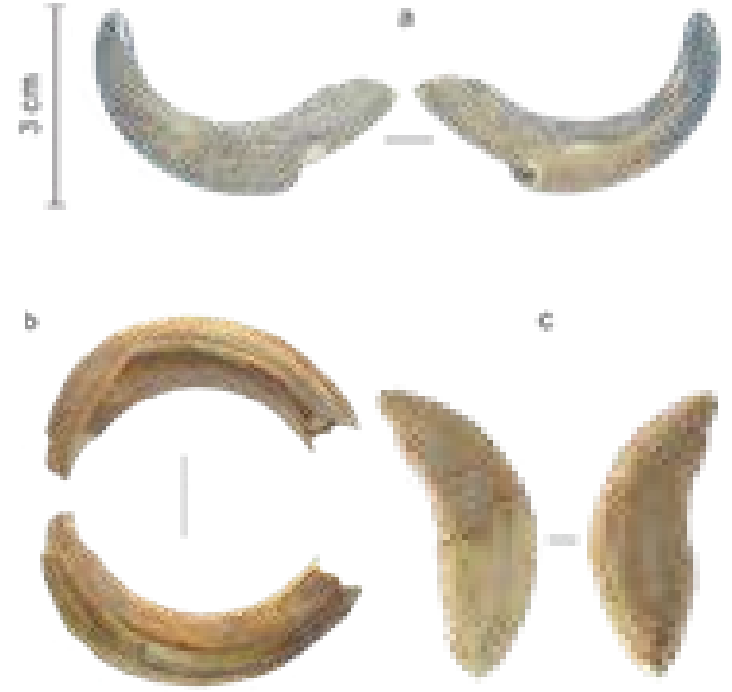

F

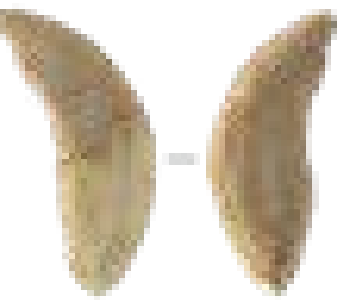

d
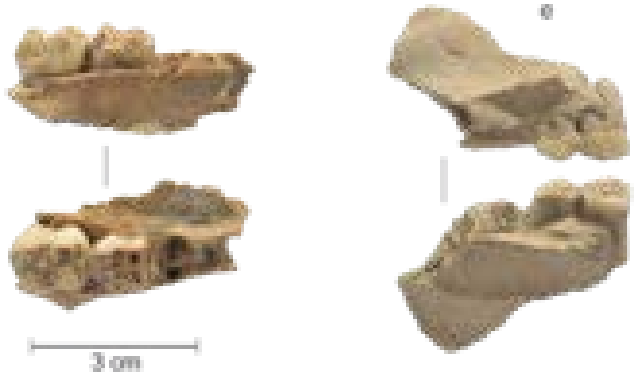

f
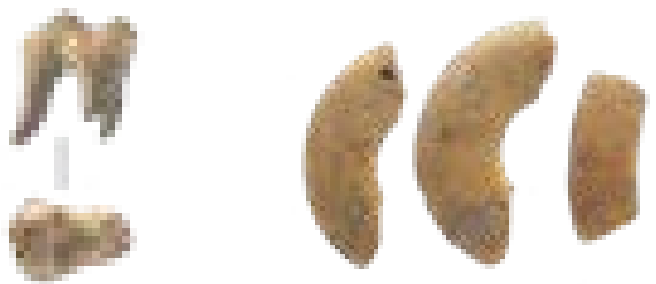

Gambar 4. Spesimen Gigi Suidae yang ditemukan di Liang Panningnge (Sumber: Dokumen Saiful, 2019)

Hasil identifikasi di atas dianalisis dengan menggunakan Software Statistical Package Social Science (SPSS) dan R. Hasil analisis SPSS kemudian digunakan untuk menginterpretasikan bentuk eksploitasi suidae oleh penghuni Liang Panningnge. 


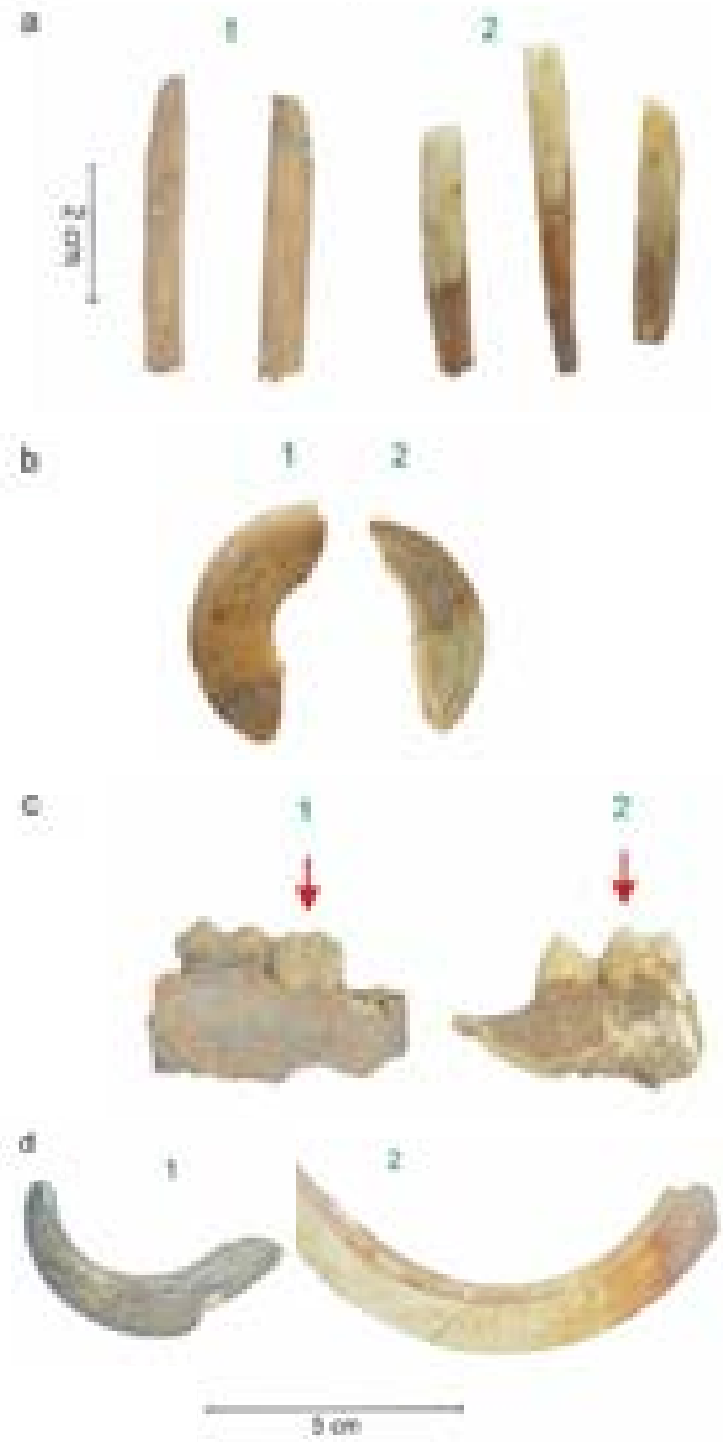

Gambar 5. Gigi Sus celebensis dan Babyrousa celebensis; (a1) incisor Babyrousa celebensis dan (a2) incisor Sus celebensis; (b1) upper incisor Babyrousa celebensis dan (b2) upper incisor Sus celelebensis; (c1) lower premolar 4 Babyrousa celebensis dan (c2) lower premolar 4 Sus celebensis; (d1) upper canine/tusk Babyrousa celebensis dan (d2) lower canine Sus celebensis (Sumber: Dokumen Saiful, 2019)

Dalam penelitian ini cara mendapatkan suidae, apakah melalui perburuan atau pemeliharaan, dapat diketahui berdasarkan analisis LEH (Linear Enamel Hypoplasia). LEH adalah garis atau depresi pada permukaan mahkota gigi (crown) yang dapat memberikan gambaran tentang kondisi lingkungan yang diadaptasi oleh suidae (Dobney \& Ervynck, 1998; Dobney \& Ervynck, 2000; Vanvoucke, S. \& Wealkens, 2007). Kondisi lingkungan yang diadaptasi oleh suidae dapat berupa kondisi alam bebas ataupun lingkungan buatan manusia (kandang) untuk memelihara suidae. Lingkungan buatan tersebut dapat menyebabkan stres pada suidae, sebagaimana tergambar pada indeks LEH yang tinggi.

\section{HASIL DAN PEMBAHASAN}

Hasil analisis tafonomi spesimen suidae dari kedua kotak ekskavasi di Liang Panningnge menunjukkan beberapa kondisi, yaitu retak (crack) 131 spesimen, korosi (corrotion) 120 spesimen, terfragmentasi dalam ukuran kecil, tetapi masih memperlihatkan bentuk yang sesungguhnya (trampling) pada 8 spesimen, dan perubahan morfologi (deformation) 4 spesimen. Semua kondisi tersebut diakibatkan oleh faktor alam. Kerusakan lainnya diakibatkan oleh hewan, berupa bekas gigitan yang terdiri atas dua tipe, yaitu lubang akibat gigitan gigi taring (pit) 40 spesimen dan lubang akibat gigitan gigi seri (tooth mark) 49 spesimen. Hasil ini menunjukkan bahwa pengaruh tafonomi akibat alam dan hewan tergolong rendah, yaitu hanya $14 \%$ dari 2.505 spesimen.

Hasil identifikasi elemen menunjukkan bahwa spesimen tulang dari kedua kotak ekskavasi terdiri atas bagian elemen tengkorak dan rahang atas (skull), tulang panjang, yaitu paha depan (humerus), betis (radius-ulna) persendian kaki depan (carpal), meta carpal, jarijari kaki (phalanges), pinggul (pelvic), paha belakang (femur), lutut (patella), 
betis belakang (tibia-fibula) persendian kaki belakang (tarsal), meta tarsal, rusuk (rib) dan tulang belakang (vertebrae) (Gambar 3). Adapun spesimen gigi yang teridentifikasi adalah gigi seri atas dan bawah (incisor 1, 2, 3), gigi taring atas dan bawah (canine), gigi premolar 2, 3, 4, dan gigi geraham atas dan bawah (Gambar 4).

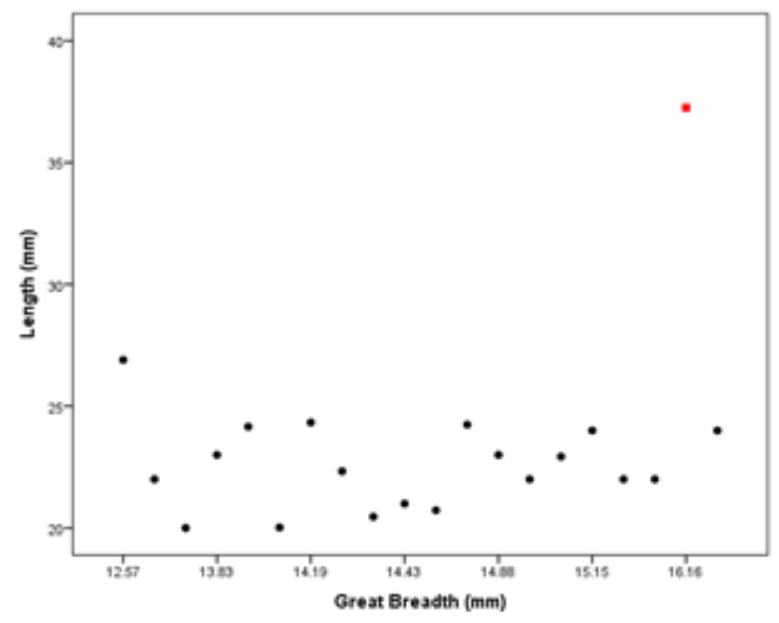

Gambar 6. Perbandingan ukuran gigi molar 3 Suidae. Plot simbol bulat merupakan ukuran gigi molar 3 suidae di Liang Panningnge. Plot simbol kotak merupakan ukuran gigi molar 3 Sus scrofa yang berasal dari Situs Kamassi, Sulawesi Barat (Sumber: Saiful, 2019)

Meskipun elemen-elemen suidae yang telah disebutkan terlihat lengkap untuk satu individu suidae, tetapi untuk mengetahui jumlah individu yang terwakili oleh elemen-elemen tersebut perlu dilihat dari hasil analisis MNI dan MNE.

Identifikasi spesies suidae di Liang Panningnge didasarkan spesimen gigi yang ada, yaitu gigi seri (incisor), taring (canine), premolar 3 dan 4, serta gigi geraham 3 (molar). Hasil identifikasi menjelaskan bahwa di gua tersebut terdapat dua spesies suidae, yaitu Sus celebensis dan Babybrousa celebensis. Perbedaan kedua spesies tersebut diketahui berdasarkan struktur dan morfologi gigi.
Gigi seri dan taring Sus celebensis memiliki enamel yang tebal, yaitu 0,44 $\mathrm{mm}-0,79 \mathrm{~mm}$. Bagian occlusal gigi seri Sus celebensis cenderung lebih datar atau menyerupai pahat, sedangkan morfologi gigi seri Babyrousa celebensis membulat bagian tengah dan runcing pada bagian occlusal. Gigitaring Sus celebensis memiliki penampang lintang yang cenderung berbentuk segitiga pada gigi taring bawah, sedangkan penampang lintang gigi taring Babyrousa celebensis berbentuk oval. Gigi premolar 3 dan premolar 4 Sus celebensis cenderung berbentuk persegi panjang, sedangkan gigi premolar 3 dan premolar 4 Babyrosa celebensis cenderung berbentuk segitiga (Gambar 5).

Hasil biometrik gigi molar 3 pada spesimen suidae dari Liang Panningnge menunjukkan variasi panjang antara 20,39-26,9 mm. Ukuran tersebut berbeda jauh dari ukuran panjang gigi molar 3 Sus scrofa yang ditemukan di Situs Kamassi, yaitu 37,35 mm (Anggraeni, 2012; Gambar 6). Dengan demikian, dapat diketahui bahwa Sus scrofa tidak ditemukan di antara spesimen dari kedua kotak ekskavasi di situs ini.

Berdasarkan hasil analisis MNI, secara keseluruhan terdapat 54 individu suidae selama penghunian Liang Panningnge, meliputi 31 individu Sus celebensis dan 23 individu Babyrousa celebensis. Pada awal penghunian (Layer 4) ditemukan 2 individu Sus celebensis dan 1 individu Babyrousa celebensis. Pada Layer 3 terdapat 13 individu Sus celebensis dan 8 individu Babyrousa celebensis Pada Layer 2 terdapat 15 individu Sus celebensis dan 13 individu Babyrousa celebensis, sedangkan pada Layer 1 setiap spesies sebanyak 1 individu (Gambar 7). 
Hasil analisis MNI terhadap kedua spesies tersebut menunjukkan bahwa telah terjadi peningkatan kebutuhan konsumsi suidae yang signifikan pada Layer 3 dan Layer 2. Berdasarkan perbandingan jumlah individu kedua spesies tersebut, tampak bahwa Sus celebensis lebih banyak dibandingkan dengan Babyrousa celebensis pada hampir seluruh masa penghunian. Hasil ini juga mengindikasikan bahwa penghuni Liang Panningnge pada setiap fase tampaknya lebih mudah atau mementingkan mendapatkan Sus celebensis dibandingkan dengan Babyrousa celebensis.

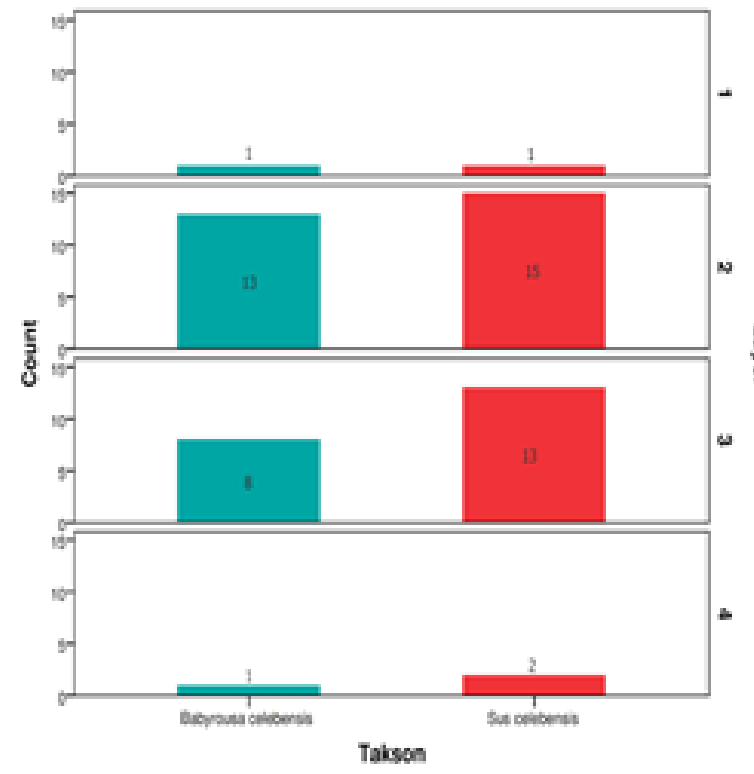

Gambar 7. MNI Babyrousa Celebensisdan Sus celebensis dari kotak S16T6 dan S8T5 (Sumber: Saiful, 2019)

Berdasarkan hasil analisis MNE terhadap spesimen suidae, diketahui bahwa pada setiap layer jenis dan jumlah elemen yang ditemukan berbeda-beda (Gambar 8). Gambar tersebut menunjukkan bahwa terjadi perbedaan jumlah antarelemen, baik pada Layer 4, Layer 3, ataupun Layer 2. Perbedaan tersebut kemungkinan berkaitan dengan aktivitas penjagalan, seleksi, dan pembagian elemen untuk dikonsumsi, mungkin dengan komunitas lain, di luar penghuni Liang Panningnge.

Menurut penuturan Johannes Rongre, salah satu warga setempat yang berasal dari Sangalla Utara, Tana Toraja biasa terlibat dalam perburuan babi, penjagalan biasanya dilakukan di lokasi perburuan apabila mereka bertemu dengan kelompok pemburu dari dusun lain. Jika perburuan hanya dilakukan oleh kelompoknya sendiri, hasil buruan akan diangkut ke dalam kampung dan di rumah salah satu anggota kelompok dilakukan penjagalan dan pembagian daging.

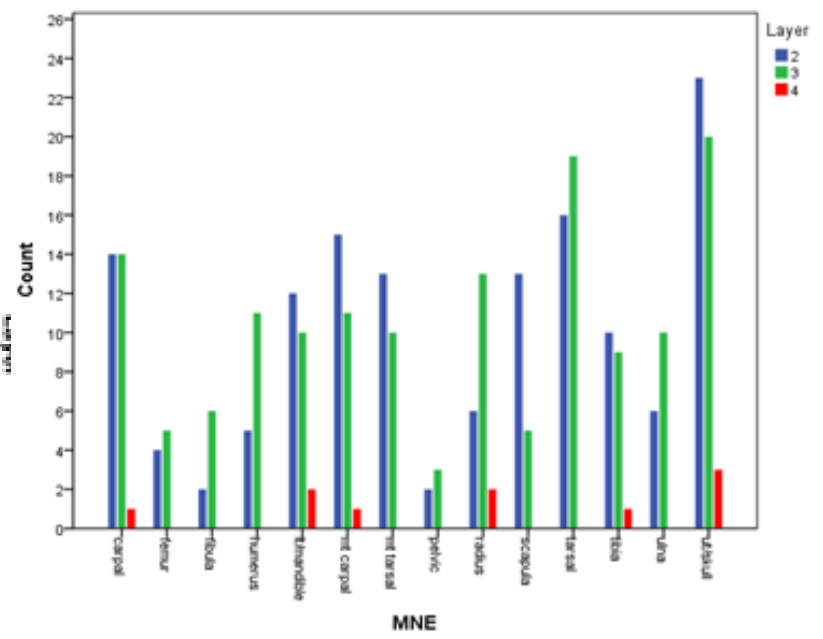

Gambar 8. MNE Suidae di Liang Panningnge, Layer 4, 3, dan 2 (Sumber: Saiful, 2019)

Studer dan Pillonel mencatat data etnografi yang berkaitan dengan penjagalan suidae di kampung Yali, Papua Barat, bahwa penduduk Yali memilih suidae yang berusia 18 bulan. Penjagalan suidae dilakukan di dalam lingkungan permukiman hanya dengan menggunakan dua alat, yaitu bambu dan beliung. Bambu digunakan untuk memisahkan tulangtulang panjang, sedangkan beliung digunakan untuk memisahkan tulang rusuk dan tulang belakang. Penggunaan 
beliung pada tulang rusuk menghasilkan jejak chop mark dan tulang pecah dengan bentuk tidak beraturan (Studer \& Pillonel, 2007).

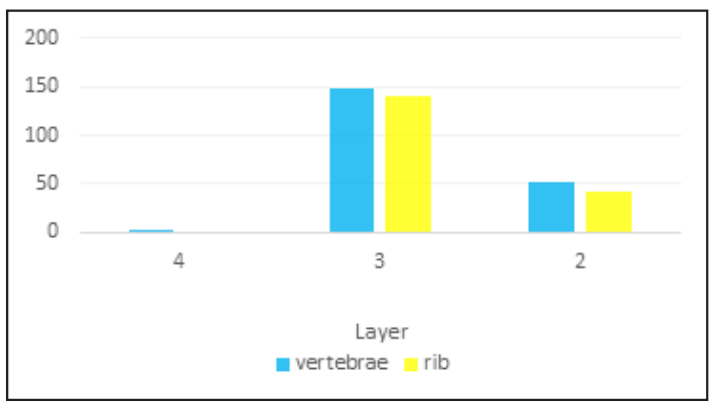

Gambar 9. NISP Tulang Belakang (Vertebrae) dan Rusuk (Rib) (Sumber: Saiful, 2019

Berdasarkan kedua informasi di atas, kemungkinan penghuni Liang Panningnge di Layer 4 melakukan penjagalan suidae di luar lingkungan gua atau di area perburuan, kemudian hasil buruan yang sudah dibagi diangkut ke dalam gua. Hal tersebut didukung dengan tidak ditemukannya tulang rusuk, sedangkan tulang belakang yang ditemukan hanya berjumlah dua (Gambar 9). Selain itu, pada layer ini juga tidak ditemukan artefak batu inti yang dapat digunakan untuk menjagal. Temuan di Layer 3 mengindikasikan bahwa penjagalan banyak dilakukan di dalam gua. Hal tersebut ditunjukkan dengan keberadaan spesimen tulang belakang dan tulang rusuk yang cukup banyak (Gambar 9). Elemen ini berasosiasi dengan 10 artefak masif yang terdiri atas kapak genggam, kapak perimbas, dan pahat genggam. Alat-alat tersebut dapat digunakan untuk melakukan penjagalan.

Keberadaan spesimen tulang belakang dan rusuk pada Layer 2 yang jumlahnya jauh lebih sedikit jika dibandingkan dengan spesimen di Layer 3 mengindikasikan bahwa penjagalan suidae di Layer 2 lebih banyak dilakukan di luar lingkungan gua. Dugaan tersebut didukung oleh sedikitnya temuan artefak batu yang berasosiasi dengan spesimen suidae, yaitu dua artefak batu berupa beliung persegi dan kapak perimbas.
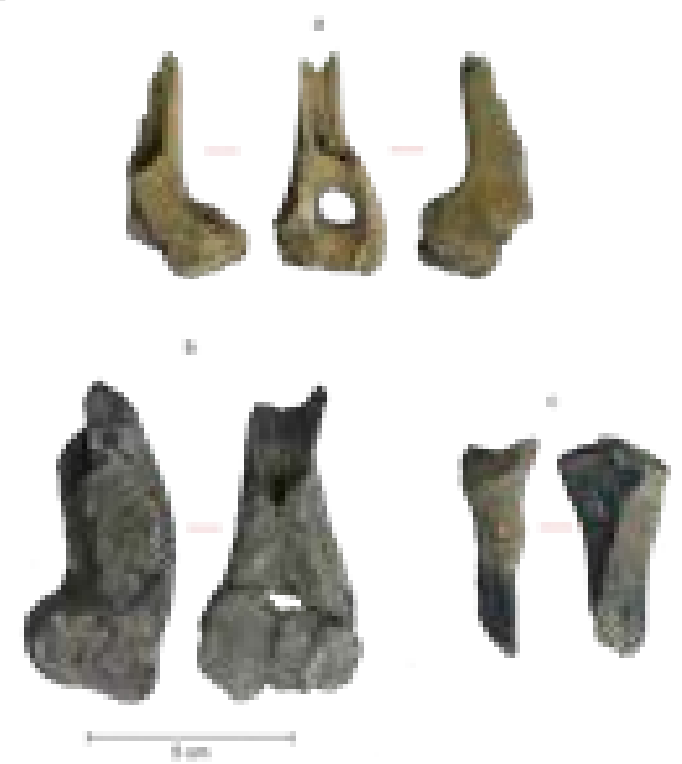

Gambar 10. Jejak Punch Markpada Tulang Panjang Suidae dari Kotak S16T6: (a) Distal Humerus dengan Kerusakan Curve, Ciri Conchoidal pada Bagian Lateral Merupakan Indikasi Punch Mark; (b) Distal Humerus dengan Kerusakan Spiral; (c) Proximal Radius dengan Kerusakan Oblique (Sumber: Saiful, 2019)

Hasil analisis MNE terhadap spesimen dari Layer 2 dan Layer 3 menunjukkan adanya dominasi elemen tertentu. Pada kedua fase tersebut penghuni Liang Panningnge tampaknya melakukan pemilihan elemen tertentu untuk dikonsumsi, yaitu mengutamakan bagian kepala dan bagian kaki (carpal-tarsal dan meta carpal-meta tarsal). Penghuni Liang Panningnge juga mengonsumsi sumsum suidae yang berasal dari bagian betis depan (radius-ulna) dan betis belakang (tibia-fibula). Selain itu, jumlah elemen tengkorak dan elemen persendian kaki yang cukup banyak jika dibandingkan dengan elemen lainnya, menjelaskan 
bahwa kemungkinan elemen tersebut sangat penting untuk dikonsumsi oleh penghuni Liang Panningnge. Jejak aktivitas konsumsi terhadap elemen-elemen tersebut terlihat pada Layer 3, berupa delapan jejak punch mark pada elemen paha depan, betis depan (radius), dan betis belakang (tibia), sedangkan pada Layer 2 ditemukan tiga jejak juga pada elemen paha depan dan betis belakang (tibia) (Gambar 10).

Ketidaklengkapan elemen suidae yang ditemukan di Liang Panningnge mengindikasikan bahwa penghuni Liang Panningnge pada penghunian fase ke- 2 dan fase ke-3 melakukan pembagian elemen suidae dengan kelompok lain yang saling kenal, yang mungkin menghuni gua-gua lain yang jaraknya tidak jauh dari Liang Panningnge, yaitu Liang Latte Masallae dan Liang Tokahue. Kedua situs tersebut memiliki ciri artefak yang sama dengan Liang Panningnge, berupa artefak serpih batu dengan tipe bilah dan mikrolit serta batu yang telah digosok.

Berdasarkan analisis usia suidae yang ditemukan di Liang Panningnge, diperoleh lima kelompok usia, yaitu juvenile (7-12 bulan), immature (13-18 bulan), subadult (19-24 bulan), adult (25-36 bulan), dan elderly (37 bulan ke atas). Akan tetapi, usia suidae yang ditemukan pada setiap layer bervariasi (Gambar 11).

Data usia suidae di atas menjelaskan tingkah laku manusia pendukung Liang Panningnge dalam mengeksploitasi suidae yang cenderung memilih suidae subadult selama fase penghunian gua, disusul dengan suidae yang lebih muda (immature). Akan tetapi, pada fase ke-2 (Layer 3) terdapat perbedaan persentase usia suidae yang dikonsumsi jika dibandingkan dengan fase ke-1 (sebelum 6000 BC) dan fase ke-3.
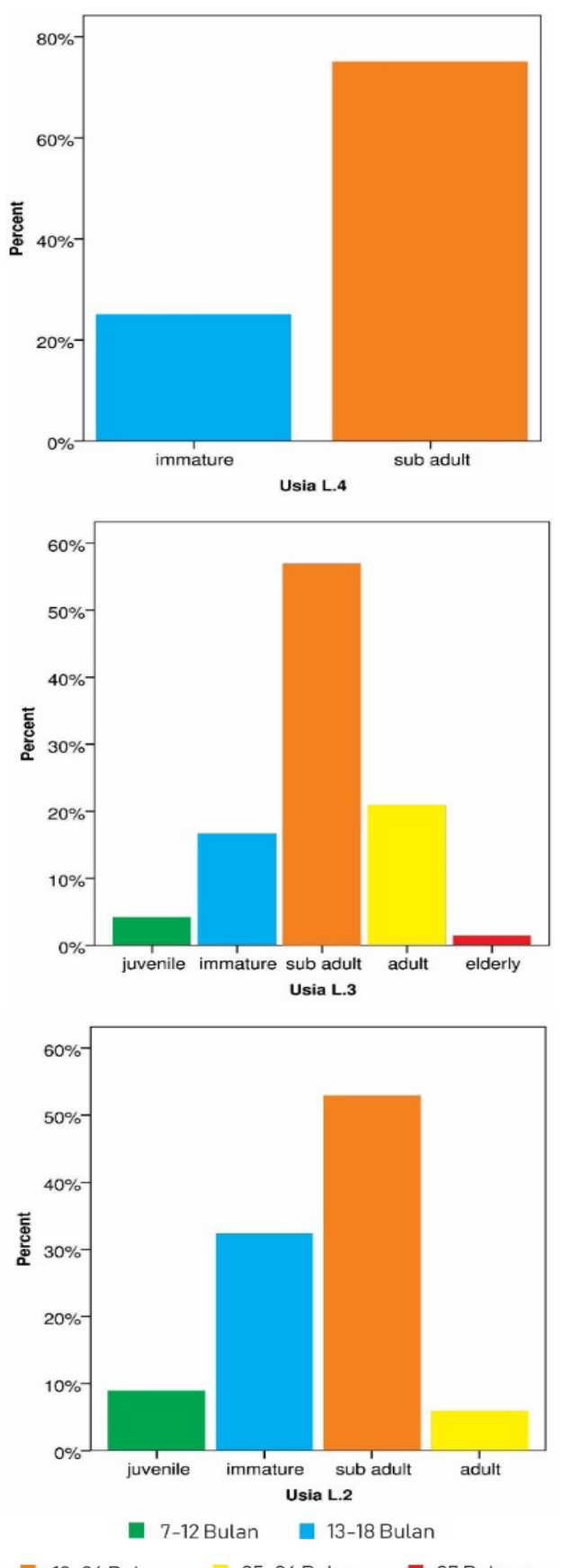

Gambar 11. Usia Suidae yang Ditemukan pada Layer 4, 3, dan 2 (Sumber: Saiful, 2019)

Pada fase ke-2, jumlah suidae yang lebih tua (adult) lebih banyak daripada suidae yang lebih muda, yaitu usia antara 13-18 bulan (immature). Keberadaan suidae usia muda, antara 7-12 bulan 
(juvenile) sejak fase ke-2 (5035-4895 BC), yang diikuti dengan peningkatan pesat jumlah suidae usia juvenile dan immature pada fase ke-3, menggambarkan awal aktivitas pemeliharaan suidae, mungkin melalui pengandangan. Indikasi aktivitas pemeliharaan didukung pula oleh indeks LEH yang tinggi.

Berdasarkan hasil analisis LEH terhadap gigi molar bawah suidae yang berasal dari Layer 3 dan Layer 2 dapat dijelaskan bahwa indeks LEH antara kedua layer memiliki perbedaan. Indeks LEH suidae pada fase penghunian ke-2 (Layer 3) berada di bawah angka 1, sedangkan indeks LEH pada fase ke-3 (Layer 2) berada di atas angka 1 (Gambar 12).

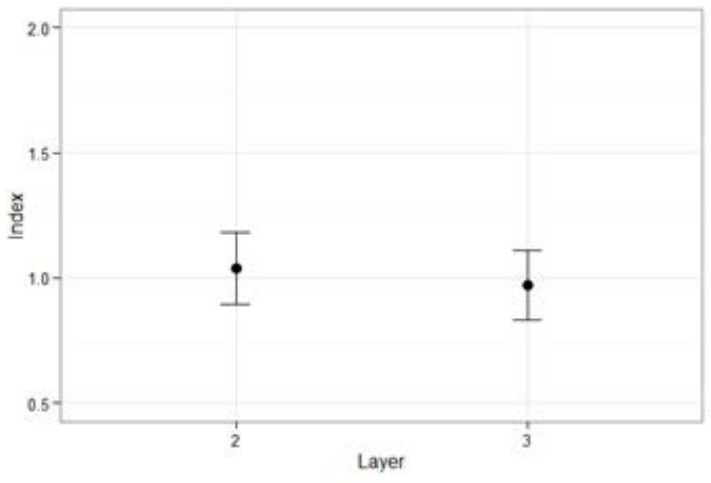

Gambar 12. Indeks LEH Layer 3 dan 2 di Liang Panningnge (Sumber: Saiful, 2019)

Indeks LEH yang rendah menunjukkan bahwa pada fase ke-2 suidae tidak mengalami tekanan atau masih berada pada habitat aslinya. Hewan tersebut masih mengonsumsi makanan yang tersedia dalam habitatnya. Sebaliknya, indeks LEH yang tinggi pada fase ke-3 menjelaskan adanya perubahan secara fisiologis pada gigi hewan ini. Perubahan tersebut diakibatkan oleh perubahan habitat dari lingkungan bebas menjadi lingkungan pemeliharaan yang berakibat pada perubahan makanannya.
Indeks LEH yang telah didapatkan dari penelitian ini didukung dengan hasil penelitian indeks LEH pada suidae dari situs-situs masa mesolitik, neolitik, dan masa logam, serta suidae liar yang hidup saat ini. LEH suidae dari situs-situs mesolitik menghasilkan indeks di bawah angka satu, sama dengan indeks LEH gigi suidae liar yang hidup saat ini. Hal ini berbeda dengan penelitian LEH pada situssitus neolitik dan zaman perunggu yang selalu menghasilkan indeks LEH berada di atas angka satu. Data tersebut menjelaskan bahwa indeks LEH yang rendah berkaitan dengan praktik perburuan, sedangkan indeks LEH yang tinggi dipengaruhi oleh praktik pemeliharaan (Dobney, Ervynck, Albarella, \& Rowley-Conwy, ley": \{“formattedCitation":"(Dobney, Ervynck, Albarella, \& Rowley-Conwy, 2004 Albarella et al., 2006; Wang, Martin, $\mathrm{Hu}$, \& Wang, 2012; Owen, 2012).

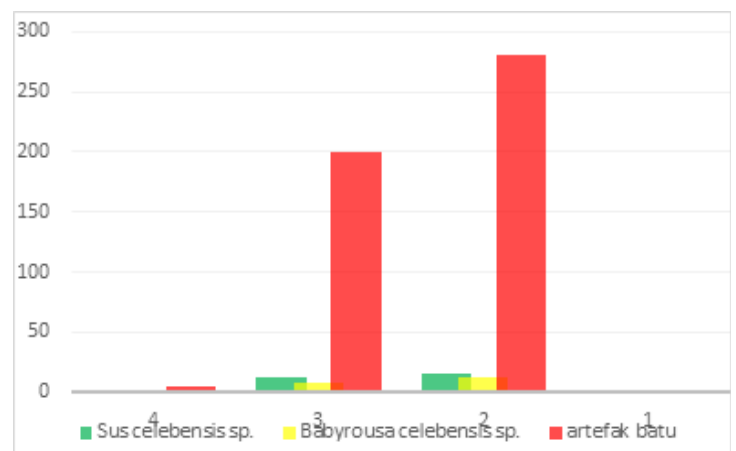

Gambar 13. Bar chart frekuensi Sus elebensis, Babyrousa Celebensis, dan artefak batu pada setiap layer (Sumber: Saiful, 2019)

Jika dilihat berdasarkan kuantitas artefak batu yang ditemukan di Kotak S8T6, terdapat hubungan signifikan antara jumlah individu suidae dan artefak batu pada setiap layer. Hal ini ditunjukkan dengan frekuensi artefak batu yang juga meningkat tajam di Layer 3 dan 2, tetapi menurun tajam pada akhir masa penghunian gua. Pada Layer 4, artefak 
batu yang ditemukan berupa tujuh penyerut. Pada Layer 3, artefak batu yang ditemukan berjumlah dua ratus, yang terdiri atas 103 Maros Point: sebanyak 15 bilah, 67 penyerut, dan 15 lancipan. Pada Layer 2 ditemukan artefak batu sebanyak 280, yang terdiri atas 171 mikrolit, 7 bilah, 19 penyerut, dan 83 lancipan. Pada Layer 1 hanya ditemukan 2 artefak batu, yaitu Maros Point dan lancipan (Tim Penelitian Kerja Sama, 2016; Gambar 13).

Berdasarkan hasil yang diuraikan di atas, dapat diketahui bahwa suidae dari Liang Panningnge di Layer 3 diperoleh dengan perburuan. Aktivitas perburuan terhadap suidae pada Layer 3 didukung dengan temuan 103 Maros Point. Pada Layer 2 muncul indikasi pengetahuan baru dalam cara mendapatkan suidae. Penghuni Liang Panningnge pada fase ini tidak lagi menjadikan perburuan sebagai satu-satunya cara untuk mengeksploitasi suidae, tetapi kemungkinan mereka telah mengenal aktivitas yang berkaitan dengan pemeliharaan.

Aktivitas pemeliharaan suidae yang kemungkinan telah berlangsung pada Layer 2 (Fase ke-3) diduga berkaitan erat dengan pemilihan usia suidae yang dikonsumsi oleh penghuni situs, yaitu immature dan subadult. Data ini menunjukkan kesamaan dengan Situs Neolitik An Son di Vietnam dan Situs Kamassi di Sulawesi Barat, bahwa suidae yang dikonsumsi berusia muda (P. J. Piper et al., 2014; Anggraeni, 2012). Selain itu, adanya gejala pemeliharaan suidae pada Layer 2 di Liang Panningnge tampaknya memiliki kaitan dengan keberadaan 171 mikrolit yang beberapa di antaranya memiliki silica gloss, tembikar, dan beliung (budaya neolitik). Artefak-artefak dari budaya neolitik dan pemeliharaan suidae berkaitan erat dengan kedatangan migran yang merupakan penutur Austronesia. Kehadiran mereka di Situs Kamassi dan Minanga Sipakko di Sulawesi Barat disertai pula dengan babi peliharaan yang sebelumnya tidak ada di Sulawesi, yaitu Sus scrofa. Sementara ini, keberadaan Sus scrofa di Liang Panningnge belum diketahui sehingga perlu dilakukan penelitian lebih intensif terkait keberadaan babi yang bukan asli Sulawesi tersebut.

Meskipun pada fase ke-3 (Layer 2) telah berlangsung aktivitas pemeliharaan suidae, hadirnya artefak batu yang berupa lancipan yang jumlahnya jauh lebih banyak jika dibandingkan dengan jumlah yang terdapat di Layer 3 (fase ke-2) mengindikasikan bahwa lancipan tersebut telah menggantikan fungsi Maros Point sebagai senjata dalam berburu. Di sisi lain, kemungkinan lancipan ini juga difungsikan sebagai alat untuk membunuh suidae peliharaan yang akan dikonsumsi.

\section{SIMPULAN}

Penelitian terhadap spesimen suidae di Liang Panningnge yang didasarkan temuan dari Kotak S8T5 dan S16T6 menghasilkan penjelasan tingkah laku penghuni gua yang berkaitan dengan eksploitasi dua spesies suidae, yaitu Sus celebensis dan Babyrousa celebensis, sebagai strategi subsistensi. Bentuk eksploitasi suidae oleh penghuni gua dalam memenuhi kebutuhan protein hewani sejak awal (sebelum 6000 $\mathrm{BC}$ ) hingga akhir masa penghunian didominasi oleh aktivitas perburuan. Hal ini dapat dibuktikan melalui keberadaan alat batu untuk berburu dan jejak-jejak penjagalan pada tulang. Dominasi Sus 
celebensis sepanjang masa penghunian gua menunjukkan bahwa hewan ini menjadi sumber protein yang lebih banyak dikonsumsi. Gerakan Sus celebensis yang lebih lamban dibandingkan dengan Babyrousa celebensis memungkinkan hewan tersebut lebih mudah diburu. Habitat Sus celebensis biasanya juga berada di sekitar lingkungan hidup manusia.

Eksploitasi suidae yang telah dilakukan oleh pendukung budaya Toalean di Liang Panningnge memperlihatkan adanya pertimbangan faktor usia suidae yang dikonsumsi serta faktor sosial, yaitu pembagian hewan dengan kelompok yang tinggal berdekatan sehingga hanya bagian tubuh tertentu saja yang ditemukan selama fase penghunian Liang Panningnge.

Berdasarkan hasil analisis LEH dapat diketahui bahwa pada fase ke-3 masa penghunian Liang Panningnge telah terjadi praktik pemeliharaan suidae. Akan tetapi, saat ini belum dapat ditentukan dengan pasti spesies mana yang telah dipelihara oleh para penghuni gua, mengingat ukuran gigi molar kedua spesies yang ditemukan rata-rata hampir sama. Karena karakter Sus celebensis dan dominasi spesies ini di Liang Panningnge, tidak mengherankan jika spesies inilah yang kemungkinan dipilih untuk dipelihara. Gejala pemeliharaan suidae yang dilakukan oleh penghuni Liang Panningnge tersebut kemungkinan dipengaruhi oleh kontak dengan pendukung budaya neolitik yang telah mengenal pemeliharaan Sus scrofa.

\section{- Ucapan Terima Kasih}

Artikel ini disusun berdasarkan tesis yang ditulis untuk memperoleh gelar magister dalam bidang Arkeologi pada Program Studi Magister Ilmu Arkeologi, Fakultas Ilmu Budaya, Universitas Gadjah Mada dengan pembimbing Dr. Anggraeni, M.A. Data hasil ekskavasi dari Liang Panningnge dapat dianalisis berkat izin yang diberikan oleh para peneliti. Untuk itu, ucapan terima kasih ditujukan kepada Prof. Dr. Akin Duli, Dr. Muhammad Nur, Dr. Hasanuddin, Prof. Dr. Stephen Cia Ming Soon, Drs. Budianto Hakim, Prof. Gerrit Van den Bergh, Fakhri, Fardi Ali Syahdar, Suryatman, Hasliana, Muhammad Ardiansyah, Muhammad Putra Hudlinas, Khairul Al Anshari, Rudy, Johannes Rongre S.S., M.Hum. dan berbagai pihak yang dengan cara masing-masing telah membantu selama proses penelitian berlangsung.

\section{DAFTAR PUSTAKA}

Albarella, U., Dobney, K., \& Rowley-Konwy, P. (2006). The Domestication of the Pig (Sus scrofa): New Challenges and New Approaches. In M. A. Zeder, D. G. Bradley, E. Emshwiller, \& B. D. Smith (Eds.), Documenting Domestication: New Genetic and Archaeological Paradigm (pp. 209-227). Berkeley: University of California Press.

Anggraeni. (2012). The Austronesian Migration Hypothesis as Seen from Prehistoric Settlements on the Karama River, Mamuju, West Sulawesi. The Australian National University.

Anggraeni, Simanjuntak, T., Bellwood, P., \& Piper, P. (2014). Neolithic Foundation in Karama Valley, West Sulawesi, Indonesia. Antiquity, 88, 740-756.

Aubert, M., Brumm, A., Ramli, M., Sutikna, T., Saptomo, W., \& Hakim, B. (2014). Pleistocene Cave Art From Sulawesi, Indonesia. Nature, 514 
Berg, G. D. (2009). The Liang Bua Faunal Remains: a 95 kyr Sequence from Flores, East Indonesia. Human Evolution, 57, 527-537.

Dobney, K., \& Ervynck, A. (1998). A Protocol of Recording Linear Enamel Hypoplasia on Archaeological Pig Teeth. International Journal of Osteoarchaeology, 8, 263-273.

Dobney, K., \& Ervynck, A. (2000). Interpreting Developmental Stress in Archaeological Pigs: the Chronology of Linear Enamel Hypoplasia. Journal of Archaeological Science, 27, 597-607.

Dobney, K., Ervynck, A., Albarella, U., \& Rowley-Conwy, P. (2004). The Chronology and Frequency of a Stress Marker (Linear Enamel Hypoplasia) in Recent and Archaeological Population of Sus Scrofa in North-West Europe, and the Effect of Early Domestication. J. Zool, 264, 197-208.

Fakhri. (2018). Arkeo Fauna Kawasan Karst Bontocani Kabupaten Bone, Sulawesi Selatan. Walennae, 16(2), 1-38.

Fernandes, Y., \& Andrews, J. P. (2016). Atlas of Taphnomic Identification. London: Springer International Publishing.

Glover, I. (1975). Survey and Excavation in the Maros District, South Sulawesi, Indonesia. London: Intitute of Archaeology.

Groves, C. P. (2006). Domesticated and Commensal Mammal of Austronesia and Their Histories. In P. Bellwood, J. J. Fox, \& D. Tryon (Eds.), The Austronesian: Historical and Comparative Perspective (pp. 161-172). Canberra: ANU E Press.

Hasanuddin. (2017). Gua Panningnge di Mallawa, Maros: Kajian tentang Gua Hunian Berdasarkan Artefak Batu dan Sisa Fauna. Naditira Widya, 11, 81-96.

Hasanuddin. (2018). Prehistoric Site in Kabupaten Enrekang, South Sulawesi. In S. O'Connor, D. Bulbeck, \& J. Meyer (Eds.), The Archaeology of Sulawesi: Current Research on the Pleistocene to the Historic Period.Terra Australis 48 (pp. 171-190). Canberra: ANU Press.

Heekeren, H. R. Van. (1972). The Stone Age of Indonesia Second Revised Edition. The Hague: Martinus Nijhoff.

Imanuella, S. K. (2017). Mangrara Banua Merawat Memori Orang Toraja (Upacara Penahbisan Tongkonan di Toraja, Sulawesi Selatan. Jurnal Ilmu Budaya, 5, 22-34.

Larson, G., \& Fuller, D. Q. (2014). The Evolution of Animal Domestication. Reviews in Advance, $66,115-136$.

Lyman, R. L. (2008). Quantitative Palaeozoology. New York: Cambridge University Press.

Meijaard, E., Haile, J., Gongora, J., \& Larson, G. (2015). The Evolution of Suidae. Reviews in Advance, 26, 11-38.

Mulvaney, D. J., \& Soejono, R. P. (1970). Archaeology in Sulawesi, Indonesia. Antiquity, 45, $26-33$.

O'Connor, T. (2000). The Archaeology of Animal Bones. Great Britain: Sutton Publishing.

Olsen, S. L., \& Glover, I. (2004). The Bone Industry of Ulu Leang 1 and Leang Burung 1 Rockshelters, Sulawesi, Indonesia in its Regional Context. Modern Quaternary Research in Indonesia, 18, 273-299.

Owen, J. T. (2012). Morphological Variation in Wild and Domestic Suids. Durham University.

Piper, P. J., Campos, F., Kinh, D. N., Amano, N., Oxenham, M., Hoang, B. C., ... Willis., A. (2014). Early Evidence for Pig and Dog Husbandry from the Neolithic Site of An Son, Southern Vietnam. International Journal of Osteoarchaeology, 24, 68-7. 
Piper, P. J., Hung, H. C., Campos, F. Z., Belwood, P., \& Santiago, R. (2009). A 4000 YearOld Introduction of Domestic Pig into the Philippines Archipelago: Implicaton for Understanding Routes of Human Migration Through Island Southeast Asia and Wallacea. Antiquity, 83, 687-695.

Piper, P. J., Nguyen, K. T. K., Tran, T. K. Q., Wood, R., Castillo, C. C., Weisskopf, A., ... Bellwood, P. (2017). The Neolithic Settlement of Loc Giang on the Vam Co Dong River, Southern Vietnam and Its Broader Regional Context. Archaeological Research in Asia, 10, 32-47.

Piper, Philip J., Campos, F. Z., \& Hung, H. (2009). A Study of the Animal Bones Recovered from Pits 9 and 10 at the Site of Nagsabaran in Northern Luzon, Philippines. Hukay, 14, 47-90.

Reitz, E. J., \& Wing, E. S. (2008). Zooarchaeology. New York: Cambridge University Press.

Saiful, A. M. (2019). Suidae dalam Strategi Subsistensi Penghuni Liang Panningnge, Maros, Sulawesi Selatan. Universitas Gadjah Mada.

Simons, A., \& Bulbeck, D. (2004). Late Quaternary Faunal Succesion in South Sulawesi, Indonesia. In S. G. Keates \& J. M. Pasveer (Eds.), Modern Quaternary Research in Indonesia (pp. 177-184). London: A.A. Balkema.

Studer, J., \& Pillonel, D. (2007). Traditional Pig Butchery by the Yali People of West Papua (Irian Jaya): Ethnographic and Archaeological Example. In U. Albarella, K. Dobney, A. Ervynck, \& P. Rowley-Conwy (Eds.), Pig and Human 10.000 years of interaction (pp. 308-329). Oxford: Oxford University Press.

Suroto, H. (2014). Babi dalam Budaya Papua. Jurnal Arkeologi Papua, 6, 37-44.

Sutton, M. Q., \& Arkuhs, B. S. (1996). Archaeological Laboratory Methods an Introduction. USA: Kendal/Hunt Publishing Company.

Tim Penelitian Balar Sul-Sel. (2016). Laporan Penelitian di Kabupaten Enrekang, Sulawesi Selatan "Peradaban Awal di Enrekang. Makassar.

Tim Penelitian Kerja Sama Universitas Hasanuddin, Universitas Sains Malaysia, B. A. S.-S. (2016). Laporan Ekskavasi Liang Panningnge. Makassar.

Vanvoucke, S., B. C., \& Wealkens, M. (2007). Economic and Ecological Reconstruction at the Classical Site of Sagalassos, Turkey, Using Pig Teeth. In U. Albarella, K. Dobney, A. Ervynck, \& P. Conwy (Eds.), Pig and Human: 10,000 Years of Interaction (pp. 269282). New York: Oxford University Press.

Vigne, J. D., Carrere, I., Briois, F., \& Guilaine, J. (2011). The Early Process Mammal Domestication in the Near East: New Evidence from the Pre-Neolithic and Pre-Pottery Neolithic in Cyprus. In Current Anthropology (pp. 225-271).

Wang, H., Martin, L., Hu, S., \& Wang, W. (2012). Pig Domestication and Husbandry in the Middle Neolithic of the Wei River Valley Northwest China: Evidence from Linear Enamel Hypoplasia. Journal of Archaeological Science, 39, 3662-3670.

Wright, E., Viner-Daniels, S., Pearson, M. P., \& Albarella, U. (2014). Age and Season of Pig Slaughter at Late Neolitik Durington Walls (Wiltshire, UK) as Detected through a New System for Recording Tooth Wear. Journal of Archaeological Science, 52, 497-514. 


\section{- Lampiran}

Tabel 1. Spesimen Suidae dari Kotak S8T6 dan S16T6

\begin{tabular}{|c|c|c|c|c|c|}
\hline \multirow{2}{*}{ Layer } & \multicolumn{2}{|c|}{ S8T5 } & \multicolumn{2}{c|}{ S16T6 } & \multirow{2}{*}{ Jumlah } \\
\cline { 2 - 5 } & Tulang & Gigi & Tulang & Gigi & \\
\hline $\mathbf{1}$ & 9 & 6 & 4 & 0 & 19 \\
\hline $\mathbf{2}$ & 432 & 156 & 636 & 124 & 1.348 \\
\hline $\mathbf{3}$ & 348 & 100 & 474 & 178 & 1.100 \\
\hline $\mathbf{4}$ & 24 & 14 & 0 & 0 & 38 \\
\hline
\end{tabular}

Tabel 2. Kategori Usia yang Diperkenalkan oleh O’Connor (1988, 2003) dalam (Wright, Viner-Daniels, Pearson, dan Albarella, 2014:501)

\begin{tabular}{ll}
\hline $\begin{array}{l}\text { K a t e g o r i } \\
\text { Usia }\end{array}$ & Deskripsi \\
neonatal & $\mathrm{dp} 4$ belum muncul dalam proses \\
juvenile & $\mathrm{dp} 4$ digunakan, $\mathrm{m} 1$ belum digunakan \\
immature & $\mathrm{m} 1$ digunakan, $\mathrm{m} 2$ belum digunakan \\
subadult & $\mathrm{m} 2$ digunakan, $\mathrm{m}$ 3 belum digunakan \\
adult & $\mathrm{m}$ 3 digunakan \\
elderly & dentin digunakan sampai bagian paling bawah \\
\hline
\end{tabular}

Tabel 3. Tipe Artefak Batu yang Ditemukan di Liang Panningnge Kotak S8T6, S8T5, S16T6 dan S17T6*

\begin{tabular}{|c|c|c|c|c|c|c|c|c|c|c|c|}
\hline Spit & $\begin{array}{c}\text { Serpih } \\
\text { Utuh }\end{array}$ & Bilah & $\begin{array}{l}\text { Lan- } \\
\text { cipan }\end{array}$ & $\begin{array}{c}\text { Mikro- } \\
\text { lit }\end{array}$ & $\begin{array}{c}\text { Maros } \\
\text { Point }\end{array}$ & $\begin{array}{c}\text { Penye- } \\
\text { rut }\end{array}$ & $\begin{array}{c}\text { Batu } \\
\text { Inti }\end{array}$ & $\begin{array}{c}\text { Batu } \\
\text { Pemukul }\end{array}$ & $\begin{array}{c}\text { Batu } \\
\text { Pelandas }\end{array}$ & $\begin{array}{c}\text { Artefak } \\
\text { Masif }\end{array}$ & $\begin{array}{l}\text { Beli- } \\
\text { ung }\end{array}$ \\
\hline 1 & 34 & & & & 1 & & 0 & & & & \\
\hline 2 & 145 & & 1 & & & & 2 & & & & \\
\hline 3 & 381 & & 1 & 8 & & 2 & 9 & & & & \\
\hline 4 & 836 & 5 & 8 & 8 & & 2 & 31 & 2 & & 1 & \\
\hline 5 & 1107 & 7 & 9 & 12 & & 3 & 37 & 1 & & & 1 \\
\hline 6 & 1776 & 3 & 13 & 27 & & 1 & 80 & 1 & & & \\
\hline 7 & 1771 & 5 & 12 & 47 & & 1 & 81 & 3 & & & \\
\hline 8 & 3238 & 21 & 28 & 49 & & 6 & 108 & 3 & 1 & & \\
\hline 9 & 1239 & 2 & 12 & 20 & & 4 & 39 & 1 & & & \\
\hline 10 & 161 & 1 & & & & 1 & 5 & & & & \\
\hline 11 & 98 & 2 & & & 3 & 1 & 19 & & & & \\
\hline 12 & 509 & 4 & & & 30 & 12 & 7 & 2 & & 5 & \\
\hline 13 & 354 & 6 & & & 26 & 6 & 2 & & & 1 & \\
\hline 14 & 389 & 23 & 1 & & 10 & 14 & 12 & 2 & & 1 & \\
\hline 15 & 1065 & 14 & 1 & & 29 & 19 & 24 & & & & \\
\hline 16 & 475 & & 7 & & 4 & 15 & 14 & & & 2 & \\
\hline 17 & 170 & 1 & 6 & & 1 & & 7 & & & 1 & \\
\hline 18 & 123 & & & & & & 2 & & & & \\
\hline 19 & 48 & & & & & 2 & 0 & & & & \\
\hline
\end{tabular}


PURBAWIDYA

Vol. 8, No. 2, November 2019: 79 -96

\begin{tabular}{|c|c|c|c|c|c|c|c|c|c|c|c|}
\hline Spit & $\begin{array}{l}\text { Serpih } \\
\text { Utuh }\end{array}$ & Bilah & $\begin{array}{l}\text { Lan- } \\
\text { cipan }\end{array}$ & $\begin{array}{c}\text { Mikro- } \\
\text { lit }\end{array}$ & $\begin{array}{c}\text { Maros } \\
\text { Point }\end{array}$ & $\begin{array}{c}\text { Penye- } \\
\text { rut }\end{array}$ & $\begin{array}{l}\text { Batu } \\
\text { Inti }\end{array}$ & $\begin{array}{c}\text { Batu } \\
\text { Pemukul }\end{array}$ & $\begin{array}{c}\text { Batu } \\
\text { Pelandas }\end{array}$ & $\begin{array}{c}\text { Artefak } \\
\text { Masif }\end{array}$ & $\begin{array}{l}\text { Beli- } \\
\text { ung }\end{array}$ \\
\hline 20 & 48 & & & & & 2 & 0 & & & & \\
\hline 21 & 103 & & & & & 3 & 3 & & & & \\
\hline 22 & 5 & & & & & & 2 & & & & \\
\hline \multicolumn{12}{|l|}{23} \\
\hline \multicolumn{12}{|l|}{24} \\
\hline \multicolumn{12}{|l|}{25} \\
\hline & 14075 & 94 & 99 & 171 & 104 & 94 & 484 & 15 & 1 & 11 & 1 \\
\hline
\end{tabular}

*Sumber:Laporan Kerja Sama Universitas Hasanuddin, Universitas Sains Malaysia, Balai Arkeologi Sulawesi Selatan2016, kotak S8T6.

Catatan: Tipe artefak masif dan beliung yang diidentifikasi dalam penelitian ini berasal dari Kotak S8T5, S16T6 dan S17T6 